\title{
DESCRIPTION OF MATHEMATIC PROBLEM SOLVING ABILITY FOR CLASS X SENIOR HIGH SCHOOL STUDENTS BASED ON POLYA STEPS
}

\section{DESKRIPSI KEMAMPUAN PEMECAHAN MASALAH MATEMATIS SISWA SMA KELAS X BERDASARKAN LANGKAH-LANGKAH POLYA}

\author{
Shannasya Aulia Himawati ${ }^{1}$, Indrie Noor Aini ${ }^{2}$, Attin Warmi ${ }^{3}$ \\ 1,2,3 Universitas Singaperbangsa Karawang, Jl. HS.Ronggo Waluyo, Puseurjaya, Kec. Telukjambe \\ Tim., Kabupaten Karawang, Jawa Barat 41361, Indonesia \\ Email: 1710631050154@student.unsika.ac.id,indrie.nooraini@staff.unsika.ac.id, \\ attin.warmi@ fkip.unsika.ac.id
}

\begin{abstract}
ABSTRAK
Tujuan dari penelitian ini sebagai upaya untuk mendeskripsikan hasil kemampuan pemecahan masalah siswa pada materi SPLTV yang dilihat berdasarkan langkah-langkah Teori Polya. Subjek penelitian yang dipilih sebanyak 6 orang dari 30 siswa total kelas asal. Metode yang digunakan adalah deskriptif kualitatif. Penelitian ini dilakukan pada salah satu SMA Negeri yang terletak di Kabupaten Bekasi dengan subjek penelitian siswa kelas X sebanyak 6 orang. Teknik pengambilan data dilakukan dengan cara penyebaran instrumen tes dan kegiatan wawancara. Analisis data dalam penelitian ini dilakukan dengan mereduksi data, menyajikan data, dan menarik kesimpulan. Hasil penelitian ini menjabarkan, di mana : 1) siswa pada kategori sedang dan rendah masih belum mampu mencapai pemahaman mengenai masalah yang disajikan soal, 2) sebagian besar siswa pada kategori tinggi saja yang mampu menyusun rancangan/strategi untuk mempermudah dalam mendapatkan hasil penyelesaian dari soal yang disajikan, 3) kurangnya ketelitian, kemampuan pemahaman materi yang kurang dan tidak melaksanakannya tahap merencanakan penyelesaian menjadi faktor utama siswa melakukan kesalahan pada tahapan ini, dan 4) pada tahap memeriksa hasil jawaban, masih sangat jarang dilakukan siswa baik pada kategori tinggi, sedang dan rendah terutama dalam membuktikan kebenaran dari hasil jawaban yang telah diperoleh.
\end{abstract}

Kata Kunci: Deskripsi, Teori Polya, Kemampuan Pemecahan Matematis

\begin{abstract}
The purpose of this study as an effort to describe the results of students' problem solving abilities on SPLTV material viewed based on the steps of Polya Theory. The research subjects selected were 6 people from 30 students from the total class of origin. The method used is descriptive qualitative. This research was conducted at one of the public high schools located in Bekasi Regency with 6 students as subjects of class $X$. Data collection techniques were carried out by distributing test instruments and interview activities. Data analysis in this study was carried out by reducing data, presenting data, and drawing conclusions. The results of this study describe, where: 1) students in the medium and low categories are still not able to achieve an understanding of the problems presented by the questions, 2) most students in the high category are only able to reach this stage and make strategies to make it easier to get the results of the settlement. of the questions presented, 3) Lack of accuracy, lack of ability to understand the material and not implementing it in the planning stage of completion are the main factors that students make mistakes at this stage, and 4) students are still very rarely done in the high, medium and low categories.
\end{abstract}


Keywords: Description, Polya Theory, Mathematical Solving Ability

How to Cite: Himawati, S. A., Aini, I. N., \& Warmi, A. (2021). Description Of Mathematic Problem Solving Ability for Class X Senior High School Students Based On Polya Steps. Mathline: Jurnal Matematika dan Pendidikan Matematika, Vol. 6 No. 2, 191-206.

DOI: https://doi.org/10.31943/mathline.v6i2.226

\section{PRELIMINARY}

Mathematics in learning has a goal, one of which is to make students have the ability to solve a problem. According to the Ministry of National Education (Puadi, 2017) the ability of mathematical problem solving itself within the scope of school can be trained by means of air $\mathrm{p}$ ikir and reason when concluding a problem, improve the ability to me $\mathrm{n}$ yelesaikan problems, and improve the ability to communicate various forms of information. If you pay attention, the purpose of the learning system listed in the KTSP according to the Ministry of National Education (Puadi, 2017), the ability to solve problems must be possessed by students because it is related to students' ability to understand problems, can choose and use systematic plans, write mathematical models to determine the calculation process correctly and re-check if it feels less precise.

What makes problem solving skills important for every student to master is because according to Branca (Puadi, 2017) : a) problem solving ability itself is the main thing in a mathematics learning process, b) steps and planning are important in the process. solve problems, and c) become the basis of part of the mathematics learning process. According to Ruseffendi (Puadi, 2017) in mathematics the importance of problem solving skills is not only addressed to students who will study and explore deeper knowledge about mathematics, but can be shown to students when they find the form of mathematical problems in the form of applications in everyday life or problems of applying mathematics to mathematics. specific subject area. This is in line with what Utami said (Amalia \& Widodo, 2018) when we live our daily lives indirectly faced with various kinds and types of problems that require problem solving skills.

Hidayat and Sariningsih said that to be able to solve it requires skills such as being able to understand a problem, making it into a form of a mathematical model, then finding a solution to be able to solve a problem (Zakiyah et al., 2019). In addition, in general, there are 4 steps according to Polya in (Indrawati et al., 2019) that can be done, namely: 1) the stage where students are able to understand the problem (understanding), 2) the stage where students identify and plan penyeles ai 's (planning), 3) the stage of completion and does implement the plan calculation process ( solving) and 4) the stage of completion of the check back and make conclusions (checking). According to Jonassen (Supriyanto, 2020) the effort to solve story problems is a form of activity in the 
process of solving a problem. The form of story questions in problem solving problems usually tends to be more difficult than ordinary questions, from the form of story questions students tend to be asked to solve the problems presented by the questions, then turn them into information in the form of mathematical models and solve them based on what can be understood and planned. (Juliana et al., 2017) .

Regarding the ability to solve problems, SPLTV is a mathematical equation material which is generally presented in the form of story questions and is often associated with problems in everyday life. Ability to prepare SPLTV into a mathematical model of the problem that is presented is the purpose of basic competence in this matter, so that students are asked to mem i Liki these capabilities in order to able to solve the problems of mathematics (Azzahra et al., 2020) . And also, on this material because at the high school level it has been previously studied and it is possible to be able to understand it well. At one Senior High School located in the district upaten Bekasi observations and derive conclusions if the capabilities of the high school students of class $\mathrm{X}$ are in the low category for the problem-solving ability. Because errors are still made by most of the students as a whole in the process of solving the problem. This fact was found because students did not write down the examples in each of the variables, in which the writing of the examples of these variables would be used when making mathematical models, and this mathematical model should be able to facilitate students in solving problems.

This was also found by previous researchers, first in Rahayuningsih \& Qohar (2014) that not answering completely and most often not writing down the information requested were some of the mistakes that students made when solving problems. Then according to (Anggraeni \& Widayanti, 2019) that it was found that students were able to write down what information might contain the known and asked elements, and in general students were able to understand the problems provided. However, the lack of systematic writing makes it difficult for students in the calculation process. Plus students do not reexamine the results of the solutions that have been obtained, this often causes the results of the settlements to be inappropriate (Zakiyah et al., 2019) .

Judging from the description above, it is very necessary to understand the ability to solve a mathematical problem. Therefore, the researcher has a goal in the form of describing the completion steps according to Polya's theory indicators on SPLTV material to determine the mathematical problem solving ability of high school students.

\section{METHOD}

This type of research includes descriptive qualitative research. The research was conducted at one of the public high schools located in Bekasi district for the even semester of the 2021/2022 academic year. The questions given are questions on a system of linear equations with three variables, with a total of 5 items in the form of essays and confirmed 
by 2 experts . Validation was carried out on the test instrument. So, the research instrument can be used in this study.

Based on the results of student work, then by purposive sampling, 6 people were selected who would be classified based on 3 major categories. Classification of categories based on the category of mathematical problem solving abilities based on the opinion of Subekti, Untarti, and Muhammad (2016: 269) in (Azzahra et al., 2020).

Table 1. Classification of Categories

\begin{tabular}{cc}
\hline Category & Value Range \\
\hline High & $x \geq(\bar{x}+s)$ \\
Medium & $(\bar{x}-s)<x<(\bar{x}+s)$ \\
Low & $x \leq(\bar{x}-s)$ \\
\hline
\end{tabular}

Description : $x$ is the value of the test questions, $\bar{x}$ is the average value, $s$ is the standard deviation

Table 1. above is a table of categories for students' mathematical problem solving abilities. The classification of categories is formed based on the results of the average comparison value range and also the standard deviation of students which will then be divided into 3 categories of student classes, namely students with high, medium and low categories. This study will use several stages of data collection based on the research of Miles \& Huberman in (Anggraeni \& Widayanti, 2019), such as: data reduction, data exposure process and making conclusions.

Below is a form of test questions used as a test instrument in this research :

1. Mr. Budi's age is 28 years older than Shinta's age. Mrs. Budi's age is 6 years younger than Mr. Budi's age. If the sum of the ages of Mr. Budi, Mrs. Budi, and Shinta is 119 years, what is the sum of the ages of Shinta and Mrs. Budi?

2. Mrs. Fifi bought $2 \mathrm{~kg}$ of apples, $2 \mathrm{~kg}$ of grapes, and $1 \mathrm{~kg}$ of oranges at a price of $\mathrm{Rp}$. $67,000.00$. Mrs. Ratih bought $3 \mathrm{~kg}$ of apples, $1 \mathrm{~kg}$ of grapes and $1 \mathrm{~kg}$ of oranges at a price of Rp. 61,000.00. Mrs. Mira bought $1 \mathrm{~kg}$ of apples, $3 \mathrm{~kg}$ of grapes, and $2 \mathrm{~kg}$ of oranges at a price of Rp. 80.000,00. If Mrs. Nurul buys $1 \mathrm{~kg}$ of apples, $1 \mathrm{~kg}$ of grapes, and $4 \mathrm{~kg}$ of oranges in the same place. How much should she pay?

3. Based on solution set $\left\{\begin{array}{c}16 x+4 y=20 \\ 4 y-8 z=-28 \\ 4 x+4 z=20\end{array}\right.$ is $\{(x, y, z)\}$. The value of $x^{2}+y^{2}+z^{2}$ is?

4. A number of 3 digits whose sum is 9 . The hundreds digit is 18 of the number formed by the two following digits. The units digit is 18 of the number formed by the two leading digits. Find the number!

5. There are three numbers $\mathrm{a}, \mathrm{b}$ and $\mathrm{c}$. The average of the three numbers is 16 . The second number plus 20 equals the sum of the other numbers. The third number is equal to the sum of the other numbers minus four. Look for the numbers! 
Then after being given a problem-solving ability test question which then from the results of the student's work, a score is given according to the predetermined ability indicator. The indicators used in making this test instrument are based on the Polya completion steps according to Amalia \& Widodo in (Azzahra et al., 2020), namely: 1) the stage where students are able to understand the problem ( understanding ), 2) the stage where students identify and draw up a settlement plan ( planning ), 3) the stage of implementing the completion plan and carrying out the calculation process ( solving ) and 4) the stage of re-examining the settlement and making conclusions ( checking ).

\section{RESULT AND DISCUSSION}

One way to obtain data is to provide test questions related to the ability to solve problems in SPLTV material for class X-D science. The results of student work that have been obtained will then be described in accordance with Polya's steps. After the data on student work is obtained and the average value and percentage of student scores have been calculated, then the classification of categories is carried out as shown in Table 2:

Table 2. Results of Category Division

\begin{tabular}{cccc}
\hline $\begin{array}{c}\text { The number of } \\
\text { students }\end{array}$ & Value Range & Percentage & Category \\
\hline 4 & $x \geq 86,30$ & $13 \%$ & High \\
19 & $40,03<x<86,30$ & $63 \%$ & Medium \\
7 & $x \leq 40,03$ & $23 \%$ & Low \\
\hline
\end{tabular}

Table 2. shows the data on the results of the division of student categories based on their mathematical problem solving abilities, from 30 students as many as 4 students are students in the high category, 19 students are students in the medium category, and 7 students are students in the low category. In the selection of research subjects, researchers will choose as many as 6 people who will represent each category classification. The selection of the three categories is used to make it easier to determine problem solving abilities according to the level of classification of their respective abilities. In Table 3 are the results of the research subject data : 
Table 3. Determination of Research Subjects

\begin{tabular}{ccccccc}
\hline & High & $\begin{array}{c}\text { Total } \\
\text { value }\end{array}$ & Meidum & $\begin{array}{c}\text { Total } \\
\text { value }\end{array}$ & Low & $\begin{array}{c}\text { Total } \\
\text { value }\end{array}$ \\
\hline Student & S-17 & 95 & S-8 & 71,67 & S-26 & 23,33 \\
Code & S-20 & 91,67 & S-16 & 70 & S-12 & 25 \\
\hline
\end{tabular}

Based on the data in Table 3. is the result of determining the research subject, where obtained 6 students with 2 people each representing each category of problem solving ability. Namely, S-17 and S-20 subjects are subjects for high category students, S-8 and S-16 subjects are subjects for medium category students, and S-26 and S-12 subjects are subjects for low category students.

The research subjects that have been determined will then be analyzed and described based on the steps of problem solving abilities. The following is a description of the results in the form of a discussion of the results of category classification based on students' abilities:

\section{Understanding the problem (understanding)}

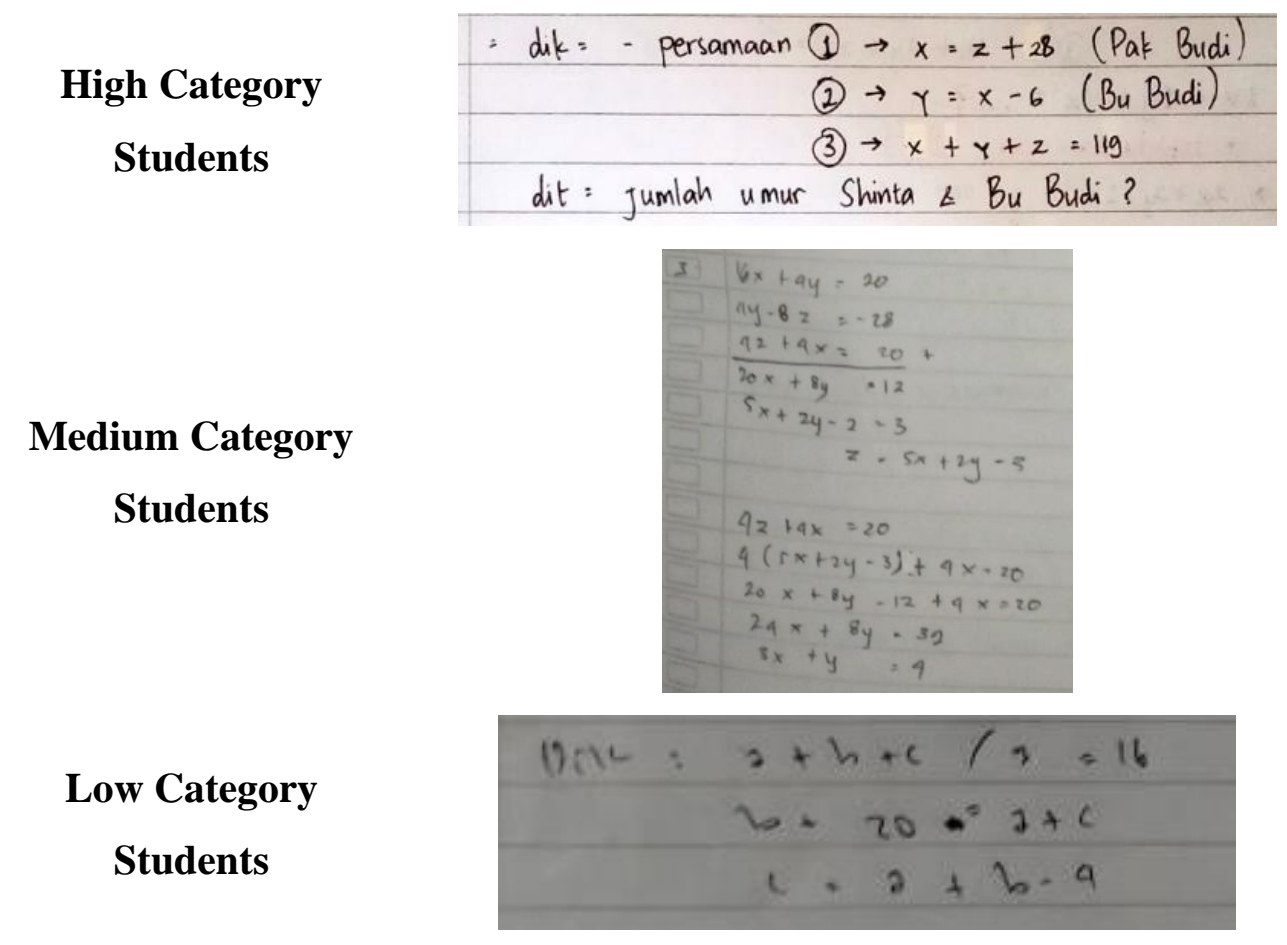

Figure 1. Results of the Understanding Stage

Figure 1 shows the results of students' calculations based on the categories of high, medium, and low problem solving abilities. In this first stage, only students with high categories, namely S-17 and S-20, were able to mention the information and things asked 
in the questions. The S-17 and S-20 are able to understand the problem presented and write it down into bullet points. This is shown by students when they can tell problems using their own language when conducting interviews regarding the results of the answers in question number 1:

Researcher : "Is it okay to mention what information you know from this question?"

S-17 : "Yes ma'am, there are three known, ma'am. The age of Mr. Budi, Mrs. Budi and Shinta with values of $x, y$ and $z$ because the question is unknown and what is being asked in the question is the sum of the ages of Shinta and Mr. Budi”

Researcher : "Are you able to find out what information is asked in this question?"

: "Yes ma'am, what is asked is the sum of the ages of Shinta and Pak Budi and what is known is the equations used to find the value of each variable"

In the medium category students, namely $S-8$ and $S-16$, both are able to understand the problem and write it down into points. However, only 3 numbers out of 5 questions that S-8 and S-16 understand and write correctly and completely. Meanwhile, the other 2 questions, S-8 and S-16 have not been able to understand the problems presented and do not write them down into bullet points. This is shown by students when conducting interviews regarding the results of answers to question number 3 :

Researcher : "Are you able to find out what information is asked in this question?"

S-8 : "Yes ma'am, there are 3 equations that are asked to find the value of the variables $x$, $y$ and $z^{\prime \prime}$

Researcher : "Why don't you write it down into known points and ask?"

S-8 : "Yes ma'am, I forgot because the equation is already known, so I immediately worked on it"

Researcher : "Are you able to find out what information is asked in this question?"

S-16 : "from the existing equations, we are asked to find the value of $x^{2}+y^{2}+z^{2}$. And I made a mistake in writing the equation ma'am in the second equation"

In S-26, he was only able to write down points related to information and questions asked in questions number 2 and 3. Unfortunately, in writing these points, it was still not appropriate and complete. While in questions number 1 and 4, S-26 did not write down these points and in question number 5 it was not answered. S-12 on question number 2, is able to write down points related to information and questions asked appropriately and completely. However, questions 1 and 3 still cannot write them down into points, and 
questions 4 and 5 have not been answered. This was shown by students when conducting interviews regarding the results of the answers to question number 2:

Researcher : "Can you mention what information you know from this question?"

S-12 : "asked what price must be paid by Mrs. Nurul"

Researcher : "Are you able to find out what information is asked in this question?"

S-26 : "looking for the value of $x y z$ and the overall price that must be paid by Mrs. Nurul"

It can be seen that the ability to understand problems related to SPLTV material from all students is still not able to know what information is part of what is known and asked. In line with Yuwono's opinion in (Azzahra et al., 2020) the cause of student errors and incompetence at this stage is that students have not sufficiently mastered the understanding of the whole material.

\section{Planning a Settlement Strategy (Planning)}

High Category

Students

Medium Category

Students

Low Category

Students

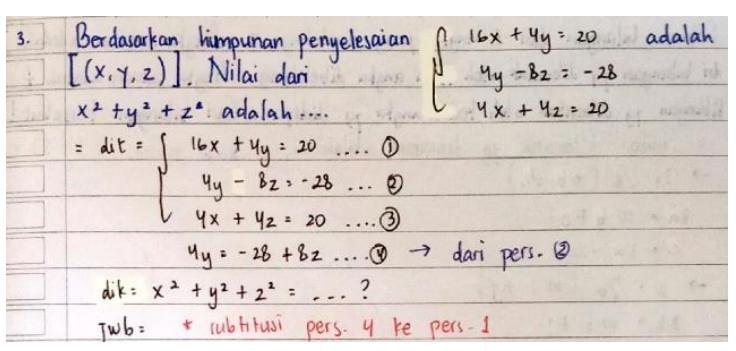

4.) Misal bliangan terscbut adaic
$a+b+c=9$
$a=1 / \theta(1 a b+c)$
$\theta a=10 b+c$
$c=\theta a \cdot 10 b$
$c=1 / \theta(10 a+b)$
$\theta c=10 a+b$
$b=8 c-10 a$
$b=8(8 a-10 b)-10 a$
$b=b y a-\theta 0 b-10 a$
$\theta 1 b=54 a$
$a=816 / 54$

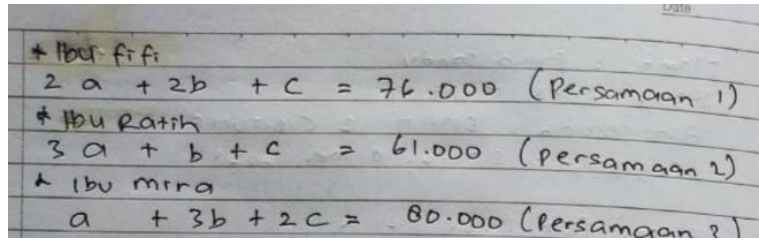

Figure 2. Planning Phase Answer Results 
Figure 2 above is the result of student calculations based on the high, medium, and low problem-solving ability categories at the stage of planning a settlement strategy. At this stage, only the S-17 is able to write down the solution plan appropriately. However, he made a mistake when he wrote the plan for the solution to be used in question number 5 . Meanwhile, S-20 was able to write down the plan for the correct solution to the 4 number of questions in a row. However, in question number 4, S-20 made a mistake in preparing a settlement plan and in question number 5 did not write a settlement solution plan. This is shown by students when they can tell problems using their own language when conducting interviews regarding the results of the answers to question number 3:

Researcher : "Did you make a plan beforehand? If so, how do you solve this problem?" $S-17$

: "I planned first ma'am, I suppose the three numbers become $a, b$ and $c$ then make an equation based on the information in the problem and solve it by using elimination and then substitution to be able to find the value of each variable"

Researcher : "Did you make a plan beforehand? If so, how do you solve this problem?" $S-20$

: "Yes ma'am, after I get all the equations I plan to use pure substitution to solve this problem"

S-8 and S-16 wrote a solution plan for the settlement, but made an error in question numbers 4 and 5 . This was shown by students when conducting interviews regarding the results of the answers to question number 4 :

Researcher : "Did you make a plan beforehand? If so, how do you solve this problem?" S-8 : "planning ma'am, but I don't know what I wrote is correct or not because I have difficulty working on question number 4"

Researcher : "Did you make a plan beforehand? If so, how do you solve this problem?" $S-16$

: "I first made it into a mathematical model, ma'am, to make it easier. But I seem to be wrong ma'am in number 4 because I immediately put it in the substitution method"

In S-26 wrote a plan for the solution to be used in question numbers 2 and 3, but in question numbers 1 and 4, S-26 made a mistake, and in question number 5 it was not answered. Then for S-12, write down the plan for the settlement solution that will be used in question number 2, for question numbers 1 and 3 S-12 made a writing error and for question numbers 4 and 5 it was not answered. This was shown by students when conducting interviews regarding the results of the answers to question number 2 :

Researcher : "Did you make a plan beforehand? If so, how do you solve this problem?" 
S-26 : "I didn't plan ahead, ma'am, I made an equation and then I calculated it into the elimination formula"

Researcher : "Did you make a plan beforehand? If so, how do you solve this problem?"

$S-12$

: "Writing the equation includes planning, isn't it, ma'am? Because after changing the problem into an equation, I immediately calculated it "

So that overall students have not been able to identify the problems in the questions, so there are still many students who find it difficult when asked to write plans/strategies to be able to solve a problem. In line with Newman's opinion in (White, 2005) that students are able to understand the problem is not directly proportional to the ability of students to identify a plan of completion to solve the problems given.

\section{Performing the Calculating Process (Solving)}

The third stage, from the 6 subjects selected, both made a lot of mistakes. Of the 5 items, only S-17 is able to carry out calculations according to the settlement plan. S-17 performs calculations according to the settlement plan, but lacks accuracy in the calculation process in getting the results of the solution in question number 5. S-20 is able to carry out calculations according to the settlement plan in question numbers 1, 2, 3 and 4 . 5, S-20 made an error during the calculation process and did not get the correct solution result. This is shown by students when they can tell problems using their own language when conducting interviews regarding the results of the answers to question number 5:

Researcher : "How do you solve and get a solution to this problem? Can you do every step well?"

S-17 : "InsyaAllah, ma'am, first after I made a mathematical model of problem number 5 I used the elimination method in equations 1 and also 2 to get the value of $b$, then re-eliminated in equations 1 and 3 to get the value of $c$. Then I substitute it into equation 1 to get the value of a"

Researcher : "How do you solve and get a solution to this problem? Can you do every step well?"

S-20 : "Yes ma'am, I use the pure substitution method to get the value of the three numbers. But after I checked the values of $a$ and $b$, I found the results were mixed, ma'am. I was wrong when I calculated it" 


\section{High Category \\ Students \\ Medium Category \\ Students}

\section{Low Category}

Studennts
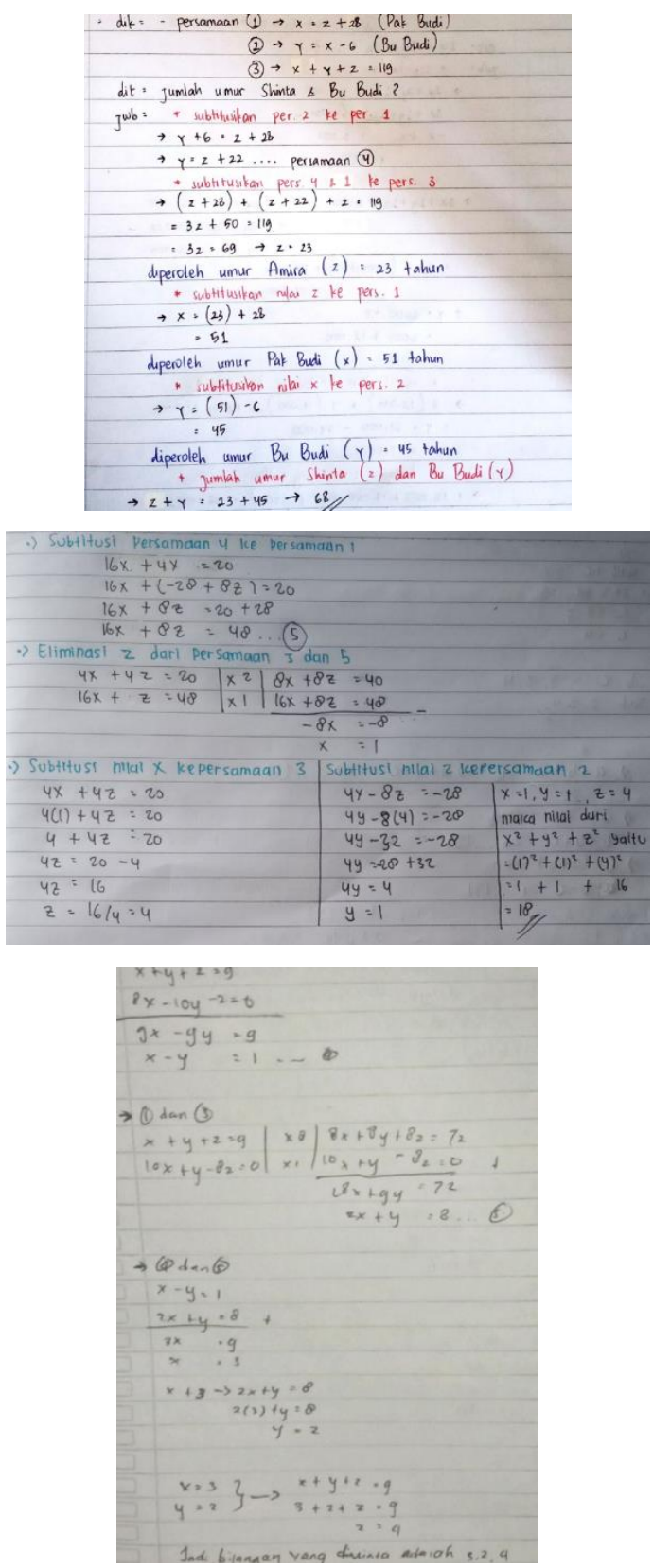

\section{Figure 3. Solving Stage Answer Results}

Referring to Figure 3 states about the results of student work with high, medium and low categories at the stage of carrying out the calculation process. The S-8, S-16, S-26 and S-12 made a mistake at the stage of executing the completion plan. The form of error that is most often made is in the form of a lack of accuracy of students when carrying out the calculation process, students are not sufficiently able to master the material so that they are not precise in carrying out formula operations and students have not reached the stage of finding the solution of the problem. This is directly proportional to the opinion of Zulfitri in (Azzahra et al., 2020) that the cause of errors in students is due to an initial error 
in planning a solution so that in the process of planning a settlement this error often occurs. And also, the main external factor that causes students to be unable to complete the calculation process is not enough time in the work process.

\title{
Checking Results and Making Conclusions (Checking)
}

And at the last stage, of the 6 subjects there were no students who were able to reach this stage on the whole question. Because there are still many mistakes made at the stage of re-checking the results of the answers that have been obtained. This was shown by students when conducting interviews regarding the results of answers to 6 subjects when asked about:

"Did you re-examine the results of the answers you have obtained and make conclusions?"

In the opinion of Zulfitri in (Azzahra et al., 2020) also said that it is very rare for students to write down the process of re-checking when students have obtained the results of the completion.

\author{
High Category \\ Students \\ Medium Category \\ Students \\ Low Category \\ Students
}
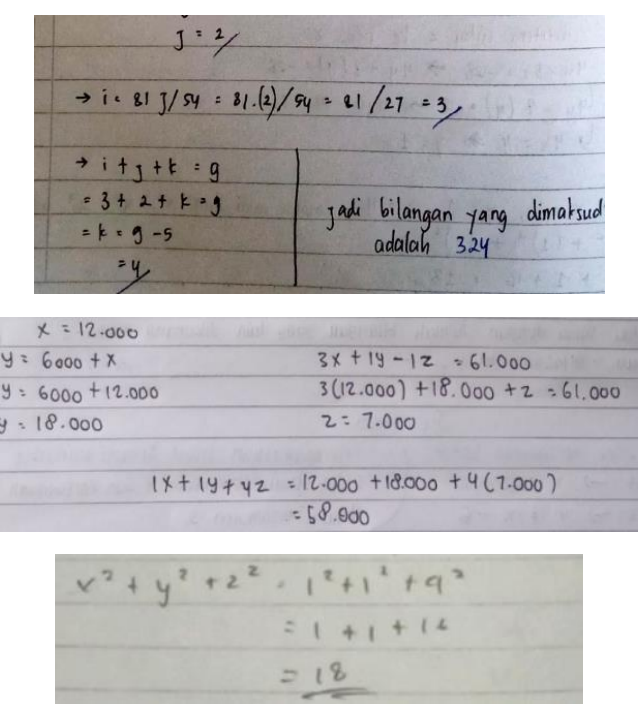

Figure 4. Checking Stage Answer Results

Figure 4 above is the result of student writing with high, medium, and low problem-solving ability categories when giving conclusions. At S-17 and S-20, they were only able to write down the stages of re-examination in several questions, namely in question numbers 1, 2 and 3. Meanwhile, S-8, S-16, S-26 and S-12 more often did not write down the stages. Check back on the answer sheet. most of them only write in the form of conclusions from the results they get without a process of re-checking whether the answers they get are correct or not. So it is not surprising that many students are able to get 
the results of the solution but it is not the right solution. Because students are only able to get the results of the problems presented without re-examining and making conclusions. Some students such as S-26 and S-12 did not do the re-examination stage because they were unable to solve the problem.

\section{CONCLUSION}

It can be seen related to the results and descriptions of problem-solving abilities based on the completion steps according to Polya on SPLTV material in class X-D science in one of the public high schools located in Bekasi district, because if it can be concluded, that: (1) starting from the stage of understanding the problem, students in the medium and low categories are still not able to reach this stage well and students in the high category can write down the information and things asked in the question, (2) then in the stage of making a settlement strategy, only students in the high category are able to achieve this stage and are able to make strategies to make it easier to get the results of solving problems. This can be interpreted that to identify a problem students still have difficulty, (3) then there is a stage of carrying out the completion plan process, where at this stage of the 6 students selected, both students in the high, medium and low categories make mistakes during the calculation process. Lack of accuracy, the ability to understand the material that is lacking and not carrying out the planning stage for completion are the main factors for students to make mistakes at this stage. (4) in the last stage, namely checking again, which is still very rarely done by students in the high, medium or low ability categories. Students only write down the process of obtaining the results of the settlement without re-examining whether the results of the settlement are correct, and students do not make conclusions.

If viewed based on the results of research and conclusions, for further research in providing ability test questions with more variations of questions will allow students to be able to answer many alternative answers so that students are able to think more in the completion process.

\section{REFERENCES}

Amalia, S. R., \& Widodo, A. N. A. (2018). Analisis Kemampuan Pemecahan Masalah Mahasiswa Melalui Model Pbl Berbasis Etnomatematika Ditinjau Dari Kepribadian Topologi Hippocrates Dan Galenus Tipe Cholearis Dan Phlegmantis. AKSIOMA: Jurnal Matematika Dan Pendidikan Matematika, 9(1), 1. https://doi.org/10.26877/aks.v9i1.2467 
Anggraeni, S. A., \& Widayanti, E. (2019). Dalam Menyelesaikan Soal Open Ended. 3(2), $115-128$.

Arifin, Z. (2019). ( Comparison of Polya and Newman Procedures on Problem Solving of Mathematics ). 3(2), 11-12.

Azzahra, R. H., Pujiastuti, H., Sultan, U., \& Tirtayasa, A. (2020). Pada Materi Sistem Persamaan Linear Tiga Variabel. 4(1), 153-162.

Berdasarkan, M., John, P., Pada, S., \& Bahasan, P. (2016). Analisis Kesalahan Siswa Dalam Pemecahan. 4(10), 973-981.

Indahsari, A. T., \& Fitrianna, A. Y. (2019). Analisis Kemampuan Pemecahan Masalah Siswa Kelas X Dalam Menyelesaikan Spldv. JPMI (Jurnal Pembelajaran Matematika Inovatif), 2(2), 77. https://doi.org/10.22460/jpmi.v2i2.p77-86

Indrawati, K. A. D., Muzaki, A., \& Febrilia, B. R. A. (2019). Profil Berpikir Siswa dalam Menyelesaikan Soal Sistem Persamaan Linear. Jurnal Didaktik Matematika, 6(1), 6984. https://doi.org/10.24815/jdm.v6i1.12200

Irianti, N. P. (2020). Analisis Kemampuan Penalaran Siswa dalam Memecahkan Masalah Matematika Berdasarkan Langkah-Langkah Polya. MUST: Journal of Mathematics $\begin{array}{llll}\text { Education, } \quad \text { Science } & \text { Technology, }\end{array}$ https://doi.org/10.30651/must.v5i1.3622

Irianti, N. P., Subanji, S., \& Chandra, T. D. (2016). Proses Berpikir Siswa Quitter dalam Menyelesaikan Masalah SPLDV Berdasarkan Langkah-langkah Polya. JMPM: Jurnal $\begin{array}{lllll}\text { Matematika Dan Pendidikan } & \text { Matematika, } & \text { 1(2), }\end{array}$ https://doi.org/10.26594/jmpm.v1i2.582

Isnarto, M. M. L. (2016). Analisis Kemampuan Pemecahan Masalah Ditinjau Dari Karakteristik Cara Berpikir Siswa Dlaam Model Problem Based Learning. Unnes Journal of Mathematics Education., 5(1). https://doi.org/10.15294/ujme.v5i1.9343

Juliana, Ekawati, D., \& Basir, F. (2017). Deskripsi Kemampuan Pemecahan Masalah Matematika Siswa Dalam Menyelesaikan Soal Sistem Persamaan Linear Dua Variabel. Jurnal Ilmiah Program Studi Pendidikan Matematika STKIP Siliwangi Bandung, 2(1), 121-133.

Manah, N. K., \& Wijayanti, K. (2017). Analysis of Mathematical Problem Solving Ability Based on Student Learning Stages Polya on Selective Problem Solving Model. Unnes Journal of Mathematics Education, 6(1), 19-26. https://doi.org/10.15294/ujme.v6i1.10855

Netriwati. (2016). Analisis Kemampuan Pemecahan Masalah Matetamatis Berdasarkan Teori Polya Ditinjau dari Pengetahuan Awal Mahasiswa IAIN Raden Intan Lampung. Jurnal Pendidikan Matematika, 7(9), 181-190.

Nuraini, Maimunah, \& Roza, Y. (2019). Analisis Kemampuan Pemecahan Masalah Siswa Kelas VIII SMPN 1 Rambah Samo Pada Materi Bangun Ruang Sisi Datar. Numerical: Jurnal Matematika Dan Pendidikan Matematika, 3(1), 63-76.

Nuryah, M., Ferdianto, F., \& Supriyadi, S. (2020). Analisis Kesalahan Siswa dalam Menyelesaikan Soal Persamaan dan Pertidaksamaan Nilai Mutlak Berdasarkan Langkah Penyelesaian Polya. Journal of Medives : Journal of Mathematics Education IKIP Veteran Semarang, 4(1), 63. https://doi.org/10.31331/medivesveteran.v4i1.983

Puadi, E. F. W. (2017). Analisis Peningkatan Kemampuan Koneksi Matematis Mahasiswa Ptik Melalui Pembelajaran Berbasis Masalah. 5. http://jurnal.upmk.ac.id/index.php/jumlahku/article/view/139

Rahmawati, N., \& Maryono, M. (2018). Pemecahan Masalah Matematika Bentuk Soal Cerita Berdasarkan Model Polya pada Siswa Kelas VIII MTs Materi Pokok SPLDV. Jurnal Tadris Matematika, 1(1), 23-34. https://doi.org/10.21274/jtm.2018.1.1.23-34

Sam, H. N., \& Qohar, A. (2016). Pembelajaran Berbasis Masalah Berdasarkan Langkah - 
Langkah Polya untuk Meningkatkan Kemampuan Menyelesaikan Soal Cerita Matematika. Kreano, Jurnal Matematika Kreatif-Inovatif, 6(2), 156. https://doi.org/10.15294/kreano.v6i2.5188

Sukestiyarno, T. (2014). Meningkatkan Karakter dan Pemecahan Masalah Melalaui Pendekatan Brain-Based Learning Berbantuan Sirkuit Matematika. Kreano: Jurnal Matematika Kreatif-Inovatif, 5(1), 82-90. https://doi.org/10.15294/kreano.v5i1.3281

Utami, R. W., \& Wutsqa, D. U. (2017). Analisis kemampuan pemecahan masalah matematika dan self-efficacy siswa SMP negeri di Kabupaten Ciamis. Jurnal Riset Pendidikan Matematika, 4(2), 166. https://doi.org/10.21831/jrpm.v4i2.14897

White, A. L. (2005). Active Mathematics In Classrooms: Finding Out Why Children Make Mistakes - And Then Doing Something to Help Them. Journal of Science and Mathematics Education in Southeast Asia, 15(4), 15-19. http://citeseerx.ist.psu.edu/viewdoc/download?doi=10.1.1.472.9065\&rep=rep1\&type $=$ pdf

Yuwono, T., Supanggih, M., \& Ferdiani, R. D. (2018). Analisis Kemampuan Pemecahan Masalah Matematika dalam Menyelesaikan Soal Cerita Berdasarkan Prosedur Polya. Jurnal Tadris Matematika, 1(2), 137-144. https://doi.org/10.21274/jtm.2018.1.2.137144

Zakiyah, S., Hidayat, W., \& Setiawan, W. (2019). Analisis Kemampuan Pemecahan Masalah dan Respon Peralihan Matematik dari SMP ke SMA pada Materi SPLTV. Mosharafa: Jurnal Pendidikan Matematika, 8(2), 227-238. https://doi.org/10.31980/mosharafa.v8i2.437

Zulfayanto, I., Lestari, S., Ilmiah, T., Malang, U. I., \& Malang, K. (2021). Analisis Kesalahan Dalam Menyelesaikan Masalah Himpunan Siswa SMP Kelas VII Ditinjau Dari Gender Analysis Of Errors In Resolving Set Problems Of Junior Junior High School Student Class VII Reviewed From Gender. 6.

Zulfitri, H. (2019). Analisis Kemampuan Pemecahan Masalah Matematika Setelah Pembelajaran dengan Pendekatan MEAs pada Materi Sistem Persamaan Linier Tiga Variabel. Jurnal Gantang, 4(1), 7-13. https://doi.org/10.31629/jg.v4i1.881 
206 Description Of Mathematic Problem Solving Ability for Class X Senior High School Students Based On Polya Steps 